\title{
Використання подрібненого субстрату ліофілізованого ксенодермоімплантата для місцевого лікування опікових хворих з інфікованими ранами III-IV ступенів
}

\author{
A. V. TSYMBALYUK, N. V. HUDA, O. O. KYRYK \\ SHEI "Ternopil State Medical University by I. Ya. Horbachevsky"
}

\section{USAGE OF THE MORSELIZED SUBSTRATE OF LIOPHILIZED XENOGRAFT FOR LOCAL TREATMENT OFTHE III-IV STAGE INFECTED BURN WOUNDS}

\begin{abstract}
Проведено комплексне дослідження результатів використання подрібненого субстрату ліофілізованого ксенодермоімплнтату для місцевого лікування інфікованих опікових ран III-IV ступенів. Застосування подрібненого субстрату ксеношкіри забезпечує очищення опікової рани, приводить до активної адсорбції токсинів 3 опікової рани та їх інактивації, стимулює крайову та острівцеву епітелізацію, що скорочує тривалість підготовки ран до автодермопластики (на 26 \%), зменшує терміни стаціонарного лікування (на 17 \%) порівняно 3 використанням на рани волого-висихаючих та мазевих пов'язок.

Complex study of the results of morselized substrate of liophilized xenograft for local usage of III-IV stage infected burns was conducted. Application of morselized substrate of xenograft provides the cleaning of burn wounds, leads to an active absorption of toxins from the burn wounds and their inactivation, promotes epithelialization process improving through regional and insular one, which at the same time reduces the duration of wound preparing for autografting (on $26 \%$ ), reduces inpatient treatment terms (on $17 \%$ ) in comparison with usage of moisture-dry and ointment dressings.
\end{abstract}

Постановка проблеми і аналіз останніх досліджень та публікацій. Традиційним стандартом лікування опікових ран III-IV ступенів залишається використання марлевих пов'язок з багатокомпонентними мазями на водорозчинній основі й розчинами антисептиків [1]. Поряд із цим, широко застосовують ранні некректомії та біологічні й синтетичні замінники шкіри для тимчасового закриття ран $[2,3]$.

Для лікування опікових ран як тимчасове біологічне покриття у відділеннях термічної травми України широко використовують ліофілізовані ксенодермоімплантати [4]. Клінічний досвід показав їх високу ефективність при поверхневих, а також при глибоких неінфікованих опіках [5]. Проте ефективність використання ліофілізованих ксенодермоімплантатів для місцевого лікування інфікованих ран із значними серозно-гнійними виділеннями $€$ незначною $[3,6]$.

Тому пошук нових препаратів для місцевого лікування опікових ран $\epsilon$ актуальним і необхідним.

Проведені нами дослідження фізико-хімічних, біохімічних та біофізичних властивостей подрібне- ного субстрату із ліофілізованого ксенодермоімплантата (ПСЛК) характеризують подрібнений субстрат як новий високоефективний препарат із високим сорбційно-антитоксичним, пластичним, метаболічним та окисно-відновним потенціалом $[6,7$, 8], що може бути використаний для розробки нових методичних схем місцевого лікування опікових ран.

У ході проведених нами експериментальних досліджень яскраво помітна різниця ефективності впливу ПСЛК на перебіг ранового процесу порівняно з використанням волого-висихаючих і мазевих пов' язок та ЛК. Особливо вирішальним є позитивний вплив ПСЛК на інфіковані рани зі значними серозно-гнійними виділеннями.

Використання подрібненого субстрату значно прискорює процес очищення ран від залишків некротичних тканин та патологічного ексудату, пришвидшує ріст якісних грануляцій та стимулює острівцеву й крайову епітелізацію.

Виходячи 3 отриманих результатів, проведено комплексне дослідження можливостей використання ПСЛК для місцевого лікування інфікованих опі- 
кових ран зі значними патологічними виділеннями, що найчастіше наявні у хворих, яких госпіталізують із запізненням і які є проблемною категорією пацієнтів опікового відділення. Було розроблено показання та методику використання подрібненого субстрату.

Матеріали і методи. За період 2012 року в Тернопільському відділенні термічної травми та пластичної хірургії обстежено 28 хворих з опіками IIIIV ступенів, в яких для місцевого лікування ран застосовували ПСЛК. Залежно від способу місцевого лікування ран хворих було поділено на 2 групи: досліджувану - 20 опечених, для лікування яких місцево на рани використовували ПСЛК, та контрольну - 8 хворих, яким використовували вологовисихаючі і мазеві пов'язки.

Причиною опікової травми обстежуваних хворих було полум'я у 12, окріп -у 16 хворих. Усі хворі з опіками III-IV ступенів госпіталізовані у відділення на 3-5 добу після травми з інфікованими опіковими ранами.

Обстежували пацієнтів з інфікованими опіковими ранами III-IV ступенів у віці від 4 до 46 років із загальною площею ураження від 5 до 36 \% поверхні тіла (в середньому $(18,7 \pm 2,3) \%)$. При цьому площа глибокого ураження становила від 2 до $22 \%$ поверхні тіла (в середньому $(8 \pm 1,8) \%$ ).

Методика застосування ПСЛК для місцевого лікування ран у хворих з опіками III-IV ступенів полягала в проведенні туалету опікових ран із використанням розчинів антисептиків, наступним насипанням на рану стерильного ПСЛК та накладанням зовнішньої марлевої пов'язки з розчином антисептиків, яка зволожувала подрібнений субстрат. Враховуючи, що потерпілі з опіками III-IV ступенів госпіталізовані на 3-5-ту добу після травми з інфікованими ранами, значними серозно-гнійними виділеннями, ранню некректомію відразу не проводили. Перев'язки в перші дні стаціонарного лікування виконували щоденно. Порошок обережно знімали з ран, щоб не травмувати молодий епітелій і не викликати капілярної кровотечі з ран. Рану промивали антисептиками і знову насипали подрібнений субстрат ліофілізованого ксенодермоімплантата. Поверх порошку накладали марлеві серветки, змочені розчином антисептика, і тугу бинтову пов' язку.

У контрольній групі перев'язки проводили щоденно з розчином декасану та водорозчинною маззю "Левоміколь".

Всі хворі отримували стандартну загальну терапію лікування опікової хвороби у вигляді системних антибактеріальних препаратів, інфузійну, десенсибілізувальну і вітамінотерапію. Крім цього, при наявності супутньої патології пацієнти отримували відповідне лікування.

Клінічну оцінку результатів лікування проводили на основі візуального контролю перебігу ранового процесу, оцінки кількості і характеру виділень, кровоточивості ран, термінів часткової епітелізації та готовності ран до автодермопластики, якості приживлення автоклаптів шкіри.

Крім того, проводили цитологічні дослідження ран за загальноприйнятою методикою.

Результати досліджень та їх обговорення. Препарат ПСЛК добре переносили хворі, не спостережено подразнення місцевих тканин чи алергічних реакцій. Відразу після початку використання для місцевого лікування ПСЛК опечені відмічали зменшення болю в рані. Також хворі спостерігали зменшення свербежу, сухості, стягування шкіри. Інфекційних ускладнень не відмічено.

Через 3-4 перев'язки з використанням ПСЛК відмічали зменшення серозно-гнійних виділень із ран, перифокального запалення. Це давало можливість у даний період всім хворим з опіковими ранами III-IV ступенів проводити етапні некректомії (рис. 1, Б). Після видалення нежиттєздатних тканин і гемостазу ран на операційному столі на рани насипали ПСЛК, який фіксували тугою пов'язкою. Перев'язки після некректомій проводили через день: ПСЛК легко і безкровно видаляли і насипали свіжий. Після проведеної некректомії вже на 5-7-му добу відмічали утворення помірно кровоточивих грануляцій, з нальотом фібрину і незначними виділеннями. Перев'язки із ПСЛК використовували до повного очищення ран.

Слід відмітити, що у 18 хворих (90 \%) порошок на ранах був зволожений, рани не висихали, виповнювались грануляціями. У 2 хворих (10 \%) спостерігали незначне нагноєння ран, що було пов'язано 3 вторинним некрозом тканин і легко корегувалося за допомогою ПСЛК.

На 14-16-ту добу у хворих при використанні ПСЛК рани були чисті, без серозно-гнійних виділень, готові до проведення автодермопластики (рис. $1, \Gamma$ ). Вже до цього часу рани зменшувалися за рахунок крайової та острівцевої епітелізації на $18-22 \%$ (в середньому $(20 \pm 1,4) \%)$. Автодермопластику ран (рис. 1, Д) у хворих досліджуваної групи проводили на 14-16-ту добу (в середньому $15 \pm 1,8)$ стаціонарного лікування (18-20 добу після травми).

У хворих контрольної групи перев'язки супроводжувалися значно сильнішими больовими відчуттями, очищення ран тривало повільніше, зменшення виділень та перифокального запалення спосте- 


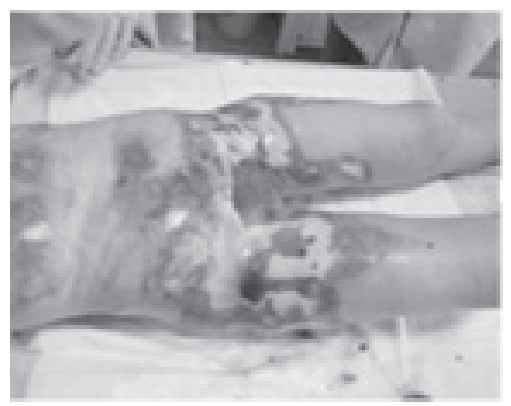

A

Опік полум'ям $24 \%$.

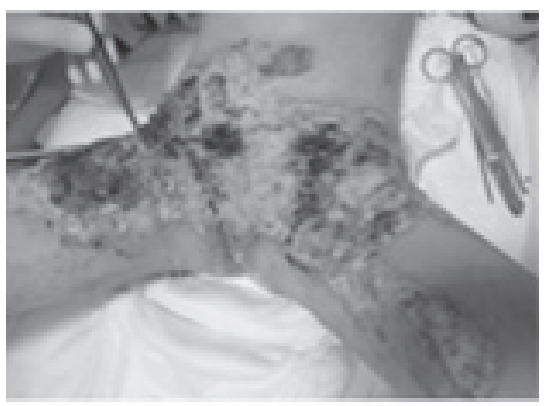

Б

Дренуюча некректомія.

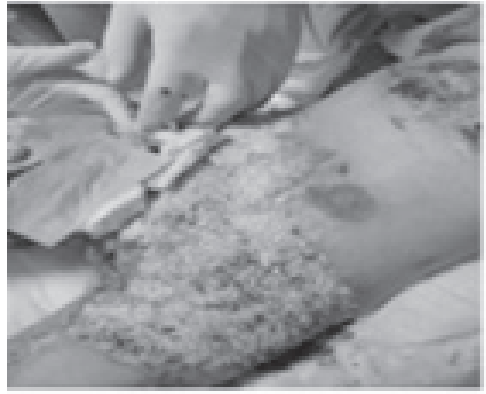

B

ПСЛК на рані.

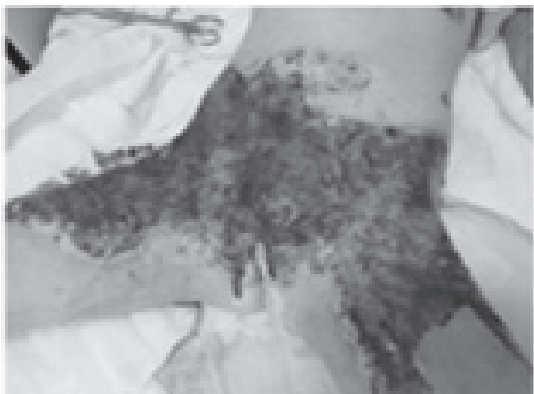

$\Gamma$

Рана після використання ПСЛК.

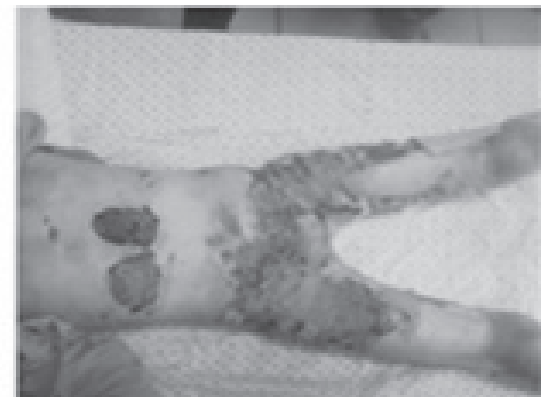

Д

Автодермопластика ран.

Рис. 1. А, Б, В, Г, Д. Хвора С. віком 4 роки. Опік окропом (III-IV ст.) спини, сідниць, кульшових суглобів, стегон, 20 \% поверхні тіла. Використання ПСЛК.

рігали тільки під час 7-8-ї перев'язок. У цей період хворим контрольної групи проводили етапні некректомії. У 4 хворих (50\%) спостерігали висихання поверхні ран з утворенням ділянок вторинного некрозу, що приводило до збільшення термінів підготовки ран до автодермопластики. Отже, у контролі рани були готові до проведення автодермопластики на 18-20-ту добу (в середньому $19 \pm 1,2$ ) стаціонарного лікування (22-24-ту добу після травми). За цей період відмічали зменшення розмірів ран на 16$20 \%$ (в середньому $18 \pm 1,3 \%$ ) за рахунок крайової та острівцевої епітелізації порівняно з площею ран при госпіталізації.

Опечені хворі досліджуваної групи перебували на стаціонарному лікуванні в середньому $(35,2 \pm 2,9)$ доби, тоді як хворі контрольної групи - до $(42,3 \pm 2,4)$ доби.

У післяопераційному періоді в обох групах лізису пересаджених автоклаптів не було. Операцію і перші перев' язки проводили під наркозом. У 2 хворих із невеликими за площею ранами перев'язки проводили без наркозу.

Проведені цитологічні дослідження ранових мазків-відбитків при прийнятті на стаціонарне лікування через 3-5 діб після травми показали запальний тип цитограм, що клінічно відповідало збільшенню кількості ранових виділень і їх нагноєнню. Відмічали у цитограмах велику кількість нейт- рофілів, лімфоцитів, моноцитів, макрофагів та полібластів.

На фоні лікування пов'язками з ПСЛК на 6-7-му добу в більшості випадків (70 \%) тип цитограми мінявся на запально-регенераторний, а в $30 \%$ випадків - залишався запальним. Кількість нейтрофілів у препараті зменшувалася до 60-70 \%, тоді як 20-35 \% клітин становили лімфоцити, фібробласти, макрофаги. Проте особливістю цитологічної картини при лікуванні ПСЛК була перевага в рані макрофагів і фібробластів, що також підтверджувало активний розвиток процесів регенерації.

Вже на 14-ту добу відмічали регенераторний тип цитограм, що характеризувався зменшенням кількості нейтрофілів до 40-50\%, різким збільшенням кількості молодих клітин сполучної тканини (профібробластів і фібробластів, макрофагів та ін.).

При дослідженні цитограм у хворих контрольної групи на 7-му та 14-ту доби обстеження відзначено запальний тип і тільки на 18-20-ту - регенераторний тип.

Висновки. 1. Відмічено значну різницю у термінах повного очищення та хірургічного закриття ран у хворих досліджуваної та контрольної груп. А саме, автодермопластику ран у хворих, лікованих ПСЛК, проводили в середньому на 5 діб (26 \%) швидше, ніж у контролі (відповідно, на $(15 \pm 1,8)$ добу 
стаціонарного лікування та $(19 \pm 1,2)$ добу). А також спостерігали скорочення перебування на стаціонарному лікуванні на 7 діб (17\%) в досліджуваній групі порівняно з контролем (відповідно, $(35,2 \pm 2,9)$ та $(42,3 \pm 2,4)$ доби).

2. Проведені цитологічні дослідження впливу ПСЛК на інфіковані опікові рани

\section{СПИСОК ЛІТЕРАТУРИ}

1. Местное медикаментозное лечение ожоговых ран: проблемы и перспективы / А. А. Алексеев, М. Г. Крутиков, А. Э. Бобровников, М. Г. Логвилава // Актуальные проблемы термической травмы.- СПб., 2009. - С. 236-237.

2. Бігуняк В. В. Використання ліофілізованих ксенодермотрансплантатів у комбустіології : методичні рекомендації / В. В. Бігуняк, М. Ю. Повстяний, Н. В. Гуда, 2003. - 21 с. 3. Алексеев А. А. Применение биологической повязки "Ксенодерм" для лечения ожоговых ран / А. А. Алексеев, Ю. И. Тюрников, С. В. Попов // Комбустиология. - 2007. - № 32. - С. 34-37. 4. Бигуняк В. В. Применение криолиофилизированой ксеногенной кожи в лечебных учреждениях Украины / В. В. Бигуняк, Н. В. Гуда, А. В. Цимбалюк // 2 съезд Ассоциации врачей экстренной медицинской помощи, посвященный десятилетию службы екстренной медицинской помощи республики Узбекистан, 21-22 октября 2011 г. - Ташкент. - С. 49-50. свідчать про позитивний вплив подрібненого субстрату на регенераторний процес вже в перший тиждень його використання, що значно прискорює процес загоєння рани. ПСЛК стимулює проліферацію фібробластів і тим самим посилює біосинтез колагену і фібрилогенез.

5. Гуда Н. В. Використання ліофілізованих ксенодермотрансплантатів для лікування дермальних опіків у потерпілих похилого і старечого віку / Н. В. Гуда, А. В. Бігуняк // Шпитальна хірургія. -2007 . - №3. - С. 47-52.

6. Бігуняк В. В. Використання подрібненого субстрату кріоконсервованої ксеношкіри в лікуванні хворих із рановим процесом / В. В. Бігуняк, Н. В. Гуда, А. В. Бігуняк // Матеріали наукового конгресу 22 з'їзду хірургів України. $-2010 .-$ Т. 1. - C. $128-129$.

7. Гуда Н. В. Вміст амінокислот та мікроелементів кріоліофілізованої ксеношкіри як показник ії біологічної активності / Н. В. Гуда, А. В. Цимбалюк // Медична хімія. - 2012. - № 1 (50). - С. 70-73.

8. Цимбалюк А. В. Антитоксичний феномен кріоліофілізованого ксенодермального субстрату / А. В. Цимбалюк, Н. В. Гуда // Медична хімія. - 2012. - № 2. - С. 64-67.

Отримано 19.02.12 